\title{
Factors associated with presentation to care with advanced HIV disease in Brussels and Northern France: 1997-2007
}

\author{
Bakhao Ndiaye ${ }^{1,2,9^{*}}$, Julia Salleron ${ }^{2}$, Anne Vincent ${ }^{3}$, Pierre Bataille ${ }^{4,9}$, Frédérique Bonnevie ${ }^{5,9}$, Philippe Choisy ${ }^{6,9}$, \\ Karine Cochonat ${ }^{7,9}$, Clotilde Fontier ${ }^{8,9}$, Habib Guerroumi ${ }^{6,8}$, Bernard Vandercam ${ }^{3}$, Hugues Melliez ${ }^{3}$, \\ Yazdan Yazdanpanah $6,9,10$
}

\begin{abstract}
Background: Our objective was to determine the frequency and determinants of presentation to care with advanced HIV disease in patients who discover their HIV diagnosis at this stage as well as those with delayed presentation to care after HIV diagnosis in earlier stages.

Methods: We collected data on 1,819 HIV-infected patients in Brussels (Belgium) and Northern France from January 1997 to December 2007. "Advanced HIV disease" was defined as CD4 count $<200 / \mathrm{mm}^{3}$ or clinically-defined AIDS at study inclusion and was stratified into two groups: (a) late testing, defined as presentation to care with advanced HIV disease and HIV diagnosis $\leq 6$ months before initiation of HIV care; and (b) delayed presentation to care, defined as presentation to care with advanced HIV disease and HIV diagnosis $>6$ months before initiation of HIV care. We used multinomial logistic regression to determine the factors associated with delayed presentation to care and late testing.

Results: Of the 570 patients initiating care with advanced HIV disease, 475 (83.3\%) were tested late and 95 (16.7\%) had delayed presentation to care. Risk factors for delayed presentation to care were: age 30-50 years, injection drug use, and follow-up in Brussels. Risk factors for late testing were: sub-Saharan African origin, male gender, and older age. HIV transmission through heterosexual contact was associated with an increased risk of both delayed presentation to care and late testing. Patients who initiated HIV care in 2003-2007 were less likely to have been tested late or to have a delayed presentation to care than patients who initiated care before 2003.

Conclusion: A considerable proportion of HIV-infected patients present to care with advanced HIV disease. Late testing, rather than a delay in initiating care after earlier HIV testing, is the main determinant of presentation to care with advanced HIV disease. The factors associated with delay presentation to care differ from those associated with late testing. Different strategies should be developed to optimize early access to care in these two groups.
\end{abstract}

\section{Background}

Despite the availability and known benefits of combined antiretroviral therapy (cART), a considerable proportion of HIV-infected patients have experienced significant immunodeficiency or disease progression before they present to care [1-7]. These patients often have poor prognoses [8], because cART reduces HIV RNA and mortality more effectively when it is initiated

\footnotetext{
* Correspondence: bakhao@yahoo.fr

${ }^{1}$ CIRE Nord, Lille, France

Full list of author information is available at the end of the article
}

early [9-13]. In a recent study conducted in France, six-month mortality among patients who initiated care with advanced HIV disease, defined as CD4 count $<200 / \mathrm{mm}^{3}$ and/or AIDS, was 13.6 higher than among patients who initiated care early [2]. Mortality rates remained higher among these patients four years after enrolment. In addition to improving outcomes at the individual level, studies have shown that effective prevention counseling and early cART initiation can also reduce the clinical and financial burden of HIV at the population level by reducing HIV transmission rates [14-18].

\section{Biomed Central}


HIV-infected patients who present to care with advanced HIV disease can be stratified into two groups: (i) patients who discover their HIV infection with an advanced HIV disease and thus initiate care late; and (ii) patients who discover their HIV infection earlier but delay initiating HIV care. Although several recent studies have evaluated the factors associated with presentation to care with advanced HIV disease [1-7], few studies have assessed the factors associated with presentation to care at this stage, by delay from first positive HIV test to presentation to care. The risk factors for presentation to care with advanced HIV disease may be different in these two groups.

The objective of this study was to determine the frequency and characteristics associated with late HIV testing with an advanced HIV disease and earlier HIV testing followed by delayed presentation to care with an advanced HIV disease among HIV-infected patients in Brussels (Belgium) and Northern France.

\section{Methods}

\section{Patients}

The Nord Pas-de-Calais region, one of 22 administrative regions in France, has a population of four million. Its cumulative incidence of AIDS is one of the lowest in France, at 299.4 cases per million inhabitants [19]. The Brussels administrative region is one of three in Belgium and has a population of one million. Its cumulative incidence of AIDS is one of the highest in Belgium, at 1,525 cases per million inhabitants [20].

We collected data on HIV-infected patients who received care at hospitals in Tourcoing, Valenciennes, Lens, Dunkerque, and Boulogne (Nord-Pas-de-Calais), as well as the Saint-Luc University Hospital in Brussels (Belgium) from January 1997 to December 2007. The Tourcoing AIDS Reference Centre of Lille University Teaching Hospital provides primary and subspecialty care to HIV-infected patients in the Lille-Roubaix-Tourcoing metropolitan area, the main urban area of the Nord Pas-de-Calais region. The Tourcoing AIDS Reference Centre has been described elsewhere in detail [21]. The hospitals in the smaller cities of Valenciennes, Lens, Dunkerque, and Boulogne also provide HIV care. SaintLuc University Hospital [22] is one of two main hospitals that provide HIV in the Brussels metropolitan area.

Patients were eligible for the study if they received a confirmatory Western blot, were aged $\geq 18$ years, had initiated care in one of the study centres, and gave informed consent to be included in the study. We considered that a patient had initiated care if he attended the study centers at least twice. We used standard questionnaires to collect complete prospective demographic, clinical, and laboratory data, as well as drug prescription information at the Tourcoing AIDS Reference Centre.
Trained technicians in Tourcoing collected follow-up data at each outpatient visit and hospitalization, or at least every 6 months. Follow-up data were entered into standard computer records. In the other study centres, baseline and follow-up data were extracted retrospectively from patient charts, using the same standardized questionnaires as those used in Tourcoing.

\section{Definitions}

Presentation with "advanced HIV disease" [7] was defined as initial presentation to care (i.e., the first clinical visit for HIV care) with CD4 count $<200 / \mathrm{mm}^{3}$ or clinically-defined AIDS. Presentation with "advanced HIV disease was stratified into two groups, according to the delay from the date of first positive HIV test result to the date of presentation to HIV care: (a) "late testing," defined as presentation with "advanced HIV disease" and HIV diagnosis $\leq 6$ months before initial presentation to care; and (b) "delayed presentation to care," defined as presentation with "advanced HIV disease" and HIV diagnosis $>6$ months before initial presentation to care. In sensitivity analysis, we varied the CD4 count threshold at which patients presented to care with CD4 cell counts $<50 / \mathrm{mm}^{3}$ to $350 / \mathrm{mm}^{3}$.

\section{Variables}

We assessed the factors associated with "late testing" and "delayed presentation to care" and compared them to the factors associated with "earlier presentation," defined as initiation of HIV care at CD4 counts $>200$ / $\mathrm{mm}^{3}$ and no AIDS.

We evaluated the demographic, clinical, biological and social characteristics of the patients included in the study. Demographic data included age at enrolment ( $<30$ years, 30-39, 40-49 and $>50$ ), gender, origin (subSaharan African immigrant or not) and HIV transmission category. Gender and origin were stratified into four groups: non-immigrant women, non-immigrant men, immigrant men and immigrant women [2]. We stratified HIV transmission into four categories, in hierarchical order: injection drug users (IDU), men who have sex with men (MSM), heterosexual contact, and other. Patients who belonged to more than one transmission group were placed in the first relevant category of the hierarchy. AIDS-defining diseases at initial presentation to care were identified using the Expanded European AIDS definition [23]. We created three categories for period of inclusion: 1997-1999, 2000-2002, and 2003-2007.

\section{Statistical Analysis}

We determined the proportion and characteristics of patients in the "delayed presentation to care" and "late testing" groups and compared them to patients who 
initiated care without advanced HIV disease. We used the chi 2 test to compare proportions and Wilcoxon's test to compare medians. In order to identify the factors that were independently associated with "delayed presentation to care" and "late testing," we entered the variables found to be associated with these outcomes in univariate analysis ( $\mathrm{p}$-value $<0.20$ ) into a multinomial logistic regression model. In multivariate analysis, associations with $\mathrm{p}$-values $<0.05$ in Wald's test model were considered to be significant. We also evaluated the interaction between study country and the variables associated with "delayed presentation to care" and "late testing" in multivariate analysis. The significance level was set to $5 \%$. All statistical analyses were performed using SPSS version 13.0 (SPSS Inc., Chicago. IL).

\section{Results}

We collected data on 1,819 patients who were followed in Northern France and Brussels from January 1997 to December 2007. The initial characteristics of patients in Northern France and Brussels were the following: median age, 35 years (interquartile range [IQR], 28-43) and 36 years (IQR, 30-43; p = 0.07); proportion of men, $70.6 \%$ (860) and 56.2\% (338; p < 0.0001); proportion of MSM, 44.9\% (541) and 28.3\% (156; p < 0.0001); proportion of IDU, 3.4\% (41) and 1.8\% (10; p < 0.0001); proportion of sub-Saharan African immigrants, 21.8\% (265) and $53.1 \%$ (319; p < 0.0001); proportion of patients who initiated care in 2003-2007, 43.9\% (535) and 54.9\% (330), proportion of patients with AIDS-defining diseases at enrolment, $16.0 \%$ (195) and $11.1 \%$ (67; p = 0.005); and median CD4 count at inclusion, $353 / \mathrm{mm}^{3}$ $(\mathrm{IQR}, 172-548)$ and $305 / \mathrm{mm}^{3}(\mathrm{IQR}, 165-485 ; \mathrm{p}=0.006)$ (Table 1).

The proportion of patients who presented to care with advanced HIV disease was $31.3 \%$ and did not differ significantly between countries (Table 2). The numbers of patients who presented to care with AIDS or CD4 counts $<50 / \mathrm{mm}^{3}$, and $<350 / \mathrm{mm}^{3}$ were $323(17.6 \%)$, and 957(52.3\%) (Table 2).

Table 3 shows the frequency of "late testing" and "delayed presentation to care" stratified by country." Nearly $17 \%$ of patients with advanced HIV disease were diagnosed earlier but delayed initiating HIV care and $83 \%$ were diagnosed late. Thirty nine of $95(41.1 \%)$ patients with delayed presentation to care and 222 of 475 (46.7\%) patients with late testing had an AIDSdefining illness at their initial presentation to care. Median time from HIV diagnosis to initial presentation to HIV care in the "delayed presentation to care" group was 55 months (IQR, 23-88). In this group, 85 patients $(89.5 \%)$ tested positive for HIV $>1$ year before enrolling in the study. The frequency of "late testing" did not differ significantly between Northern France and Belgium,
Table 1 Demographic and clinical characteristics of HIVinfected patients in 6 clinical centres in Northern France and Brussels: January 1997 to December 2007

\begin{tabular}{|c|c|c|c|}
\hline Characteristics & $\begin{array}{c}\text { Northern } \\
\text { France } \\
(n=1218)\end{array}$ & $\begin{array}{l}\text { Brussels, } \\
\text { Belgium } \\
(n=601)\end{array}$ & p-value \\
\hline \multicolumn{4}{|l|}{ Age, years } \\
\hline Median & 35 & 36 & 0.07 \\
\hline $25^{\text {th }}$ percentile & 28 & 30 & \\
\hline $75^{\text {th }}$ percentile & 43 & 43 & \\
\hline Gender & & & $<0.0001$ \\
\hline Male & $860(70.6 \%)$ & $338(56.2 \%)$ & \\
\hline Female & $358(29.4 \%)$ & $263(43.8 \%)$ & \\
\hline HIV transmission category & & & $<0.0001$ \\
\hline Men who have sex with men & $541(44.9 \%)$ & $156(28.3 \%)$ & \\
\hline Injection drug use & $41(3.4 \%)$ & $10(1.8 \%)$ & \\
\hline Heterosexual contact & $622(51.7 \%)$ & $385(69.9 \%)$ & \\
\hline $\begin{array}{l}\text { Sub-Saharan African } \\
\text { immigrant }\end{array}$ & & & $<0.0001$ \\
\hline Yes & $265(21.8 \%)$ & $319(53.1 \%)$ & \\
\hline No & $953(78.2 \%)$ & $282(46.9 \%)$ & \\
\hline Period at enrolment & & & $<0.0001$ \\
\hline 1997-1999 & 337 (27.7\%) & $124(20.6 \%)$ & \\
\hline $2000-2002$ & $346(28.4 \%)$ & $147(24.5 \%)$ & \\
\hline 2003-2007 & 535 (43.9\%) & $330(54.9 \%)$ & \\
\hline $\begin{array}{l}\text { AIDS-defining disease at } \\
\text { enrolment }\end{array}$ & $195(16.0 \%)$ & $67(11.1 \%)$ & 0.005 \\
\hline \multicolumn{4}{|l|}{ Baseline CD4 count, $/ \mathrm{mm}^{3}$} \\
\hline Median & 353 & 305 & 0.006 \\
\hline $25^{\text {th }}$ percentile & 172 & 165 & \\
\hline $75^{\text {th }}$ percentile & 548 & 485 & \\
\hline
\end{tabular}

regardless of the definition of "late presentation" used. In contrast, the rate of "delayed presentation to care" did differ significantly between countries: "delayed presentation to care" was twice as frequent in Brussels than in Northern France (Table 3).

Table 4 shows the results of multinomial logistic regression analysis. The reference category was presentation to care without advanced HIV disease. Patients aged 30-40 years (odds ratio [OR], 3.28; 95\% confidence interval $[\mathrm{CI}], 1.68-6.41$ ) and $40-50$ years (OR, 5.44; $95 \%$ CI, 2.69-11.02) were at higher risk of "delayed presentation to care" compared to patients aged $<30$ years. Compared to MSM, patients in the heterosexual contact transmission category (OR, 1.90; 95\% CI, 1.14-3.21) and IDU (OR, 3.03; 95\% CI, 1.14-9.53) were more likely to have tested earlier and presented to care with advanced HIV disease. Study inclusion in 1997-1999 was associated with "delayed presentation to care" compared to inclusion in 2003-2007 (OR, 3.20; 95\% CI, 1.88-5.43). Patients in Brussels were also more likely to have tested early and presented to care with advanced HIV disease 
Table 2 The proportion of patients who presented to care with AIDS or CD4 counts $<50 / \mathrm{mm}^{3},<200 / \mathrm{mm}^{3}$ and $<350 /$ $\mathrm{mm}^{3}$ among HIV-infected patients in Northern France and Brussels: January 1997 to December 2007

\begin{tabular}{lcccc}
\hline & & & \multicolumn{2}{c}{ Prevalence } \\
\hline Presentation to care & $\begin{array}{c}\text { Total } \\
\mathbf{n}=\mathbf{1 8 1 9}\end{array}$ & $\begin{array}{c}\text { Northern France } \\
\mathbf{n}=\mathbf{1 2 1 8}\end{array}$ & $\begin{array}{c}\text { Brussels } \\
\mathbf{n}=\mathbf{6 0 1}\end{array}$ & $\mathbf{p}$-value \\
\hline CD4 count $<50 / \mu$ l or AIDS & $323(17.6 \%)$ & $221(18.1 \%)$ & $102(17.0 \%)$ & 0.31 \\
CD4 count $<\mathbf{2 0 0 / \mu l}$ or AIDS* & $\mathbf{5 7 0 ( 3 1 . 3 \% )}$ & $\mathbf{3 7 3 ( 3 0 . 6 \% )}$ & $\mathbf{1 9 7}(\mathbf{3 2 . 8 \% )}$ & $\mathbf{0 . 1 8}$ \\
CD4 count $<350 / \mu$ l or AIDS & $957(52.9 \%)$ & $614(50.4 \%)$ & $343(57.1 \%)$ & 0.21 \\
\hline
\end{tabular}

${ }^{*}$ Advanced HIV disease.

compared to patients in Northern France (OR, 2.34; 95\% CI, 1.51-3.75).

Rates of "late testing" increased as age increased from $30-40$ years (OR, 2.00 compared to $<30$ years) to $\geq 50$ years (OR, 4.07 compared to $<30$ years; $\mathrm{p}<0.0001$ ). Compared to non-immigrant women, immigrant women (OR, 2.23; 95\% CI, 1.48-2.70), non-immigrant men (OR, 1.86; 95\% CI, 1.23-2.80), and immigrant men (OR, 2.17; 95\% CI, 2.03-4.00) were more likely to be diagnosed late. Compared to MSM, patients in the heterosexual contact transmission category were more likely to be diagnosed late (OR, 1.56; 95\% CI, 1.13-2.14). Compared to patients who enrolled in the study in 2003-2007, patients who enrolled in 2000-2002 (OR, 1.58; 95\% CI, 1.21-2.06) and 1997-1999 (OR, 1.42; 95\% CI, 1.07-1.88) were more likely to have been diagnosed late.

\section{Discussion}

We estimated the frequency of patients who presented to care with advanced HIV disease among 1,819 HIVinfected patients in the Nord-Pas-de-Calais region (France) and Brussels (Belgium) from January 1997 to December 2007. Moreover, within patients with advanced HIV disease we determined the frequency of "late testing" (i.e.; HIV diagnosis $\leq 6$ months before initial presentation to care) and "delayed presentation to care" (i.e.; HIV diagnosis $>6$ months before initial presentation to care). Finally, we assessed the potential risk factors associated with "delayed presentation to care"/ "late testing" and presentation to care with advanced HIV disease. Of the 570 patients (31.3\%) who presented to care with advanced HIV disease, 95 (16.7\%) were diagnosed early but delayed initiating HIV care for $>6$ months, and 475 (83.3\%) were diagnosed late. Older patients, sub-Saharan African immigrants, non-immigrant men and patients who enrolled in the study between 1997 and 2002 were more likely to be diagnosed late. Risk factors for "delayed presentation to care" and presentation to care with advanced HIV disease were: age 30-49 years, HIV transmission through heterosexual contact or injection drug use, enrolment in the study between 1997 and 1999, and follow-up in Brussels.

There are multiple definitions of "late presentation" or "delayed HIV diagnosis" in the medical literature. Recently, The UK Collaborative HIV Cohort (UK CHIC) Steering Committee defined presentation at a stage when there is a substantial risk of death (i.e., CD4 counts $<200 / \mathrm{mm}^{3}$ or clinically-defined AIDS) as presentation with "advanced HIV disease" and presentation with a CD4 cell count below $350 / \mathrm{mm}^{3}$, resulting in a delay in treatment initiation, as "late presentation"[7]. In this analysis we focused on patients with advanced HIV diagnosis and showed that $31.3 \%$ of patients initiated care at CD 4 counts $<200 / \mathrm{mm}^{3}$ or clinically-defined AIDS. This proportion was found to be similar in Northern France and Belgium, and is comparable to estimates from several recent European studies that used the same definition for "late presentation." In these studies, rates of "late presentation" ranged from $27 \%$ to $59 \%$ [1-7]. In our study, $16.7 \%$ of those with advanced HIV disease were aware of their HIV status but delayed initiating care for $>6$ months. Thus, late testing, rather than delay in initiating care after testing HIV positive, is the main determinant of presentation to care with advanced HIV disease. Of note, the proportion of patients who initiated care with an AIDS-defining event was comparable in patients with late testing and those

Table 3 Proportion of "delayed presentation to care" and "late testing" among HIV-infected patients who present to care late in Northern France and Brussels: January 1997 to December 2007

\begin{tabular}{|c|c|c|c|c|}
\hline & $\begin{array}{c}\text { Total } \\
\text { n/N (\%) }\end{array}$ & $\begin{array}{c}\text { Northern France } \\
\mathrm{n} / \mathrm{N}(\%)\end{array}$ & $\begin{array}{c}\text { Brussels, Belgium } \\
\mathrm{n} / \mathrm{N}(\%)\end{array}$ & p-value \\
\hline $\begin{array}{l}\text { Presentation to care with advanced HIV disease*and } \\
\text { HIV diagnosis }>6 \text { months before initiation of care }\end{array}$ & $95 / 570(16.7)$ & $44 / 373$ (11.8) & $51 / 197$ (25.9) & 0.0003 \\
\hline $\begin{array}{l}\text { Presentation to care with advanced HIV disease*and } \\
\text { HIV diagnosis } \leq 6 \text { months before initiation of care }\end{array}$ & $475 / 570(83.3)$ & $329 / 373(88.2)$ & $146 / 197(74.1)$ & 0.18 \\
\hline
\end{tabular}

* CD4 $<200$ cells/ $\mu$ l or AIDS. 
Table 4 Multivariate multinomial logistic regression analysis: Factors associated with "delayed presentation to care" and "late testing" among HIV-infected patients in Northern France and Brussels, from January 1997 to December 2007

\begin{tabular}{|c|c|c|c|c|c|c|c|c|}
\hline & \multicolumn{4}{|c|}{$\begin{array}{l}\text { "delayed presentation to care" with advanced HIV } \\
\text { disease* despite earlier HIV testing }\end{array}$} & \multicolumn{4}{|c|}{$\begin{array}{l}\text { "Late testing" and presentation to care with } \\
\text { advanced HIV disease* }\end{array}$} \\
\hline & n total & n (\%) & OR & $95 \% \mathrm{Cl}$ & n total & n (\%) & OR & $95 \% \mathrm{Cl}$ \\
\hline \multicolumn{9}{|l|}{ Age, years } \\
\hline$<30$ & 454 & $12(2.6)$ & 1.00 & & 529 & $87(16.4)$ & 1.00 & \\
\hline $30-39$ & 500 & $43(8.6)$ & 3.28 & $1.68-6.41$ & 635 & $178(28.0)$ & 2.00 & $1.82-2.70$ \\
\hline $40-49$ & 256 & $31(12.1)$ & 5.44 & $2.69-11.02$ & 344 & 119 (34.6) & 2.85 & $2.03-4.00$ \\
\hline$\geq 50$ & 134 & $9(6.7)$ & 2.48 & $0.97-6.35$ & 216 & $91(42.1)$ & 4.07 & $2.76-6.02$ \\
\hline \multicolumn{9}{|l|}{ Sex and immigrant status } \\
\hline Non-immigrant women & & & & & 235 & $52(22.1)$ & 1.00 & \\
\hline Immigrant women & & & & & 348 & $113(32.5)$ & 2.23 & $1.48-2.70$ \\
\hline Non-immigrant men & & & & & 980 & $254(25.9)$ & 1.86 & $1.23-2.80$ \\
\hline Immigrant men & & & & & 161 & $56(34.8)$ & 2.17 & $2.03-4.00$ \\
\hline \multicolumn{9}{|l|}{ HIV transmission category } \\
\hline Men who have sex with men & 550 & $23(4.2)$ & 1.00 & & 674 & $147(21.8)$ & 1.00 & \\
\hline Injection drug use & 43 & $4(9.3)$ & 3.03 & $1.14-9.53$ & 47 & $8(17.0)$ & 0.79 & $0.34-1.84$ \\
\hline Heterosexual contact & 709 & $63(8.9)$ & 1.90 & $1.14-3.21$ & 944 & 298 (31.6) & 1.56 & $1.13-2.14$ \\
\hline \multicolumn{9}{|l|}{ Study inclusion period } \\
\hline 2003-2007 & 637 & $32(4.8)$ & 1.00 & & 833 & $205(24.6)$ & 1.00 & \\
\hline 2000-2002 & 332 & $26(7.6)$ & 1.76 & $0.99-3.14$ & 467 & $151(32.3)$ & 1.58 & $1.21-2.06$ \\
\hline 1997-1999 & 333 & $37(10.8)$ & 3.20 & $1.88-5.43$ & 424 & $119(28.1)$ & 1.42 & $1.07-1.88$ \\
\hline \multicolumn{9}{|l|}{ Country of follow-up } \\
\hline France & 889 & $44(4.9)$ & 1.00 & & & & & \\
\hline Belgium & 455 & $51(11.2)$ & 2.34 & $1.51-3.75$ & & & & \\
\hline
\end{tabular}

Reference category is presentation to care without advanced HIV disease.

* CD4 $<200$ cells/ $\mu$ l or AIDS.

with delayed presentation to care. This shows that late testing is also the main reason of presentation to care with AIDS. Few studies, especially in Europe, have focused their analysis on the group of patients delaying HIV care. In the Italian Cohort Naive Antiretrovirals, $26.1 \%$ of all HIV infected patients delayed initiating care for $>6$ months after HIV diagnosis, and these patients represented $26.1 \%$ of patients with $<200 \mathrm{CD} 4$ cells $/ \mathrm{mm}^{3}$ or clinically defined AIDS upon enrolment [24]. This estimate, using the same definition, is higher than the results from our study in Northern France (11.8\% with advanced HIV disease had delayed initiating care) but close to those in the Belgium clinical cohort (25.9\% with advanced HIV disease had delayed initiating care)

Consistent with previous studies, our findings show that older patients, heterosexuals, sub-Saharan African immigrants, non-immigrant men and patients who initiated care between 1997 and 2002 were more likely to be diagnosed late with advanced HIV disease [25-32]. The risk of "late testing" increased with age, from an OR of 2.00 among patients aged $30-40$ years to 4.07 among patients aged $\geq 50$ years, compared to patients aged $<30$ years. Previous studies have estimated that the risk of "late testing" in older age groups ranges from 3 to $6.5[2,11,24,33-36]$. A recent review evaluated the psychosocial factors associated with HIV testing in highincome countries. The authors concluded that individuals generally get tested for HIV for the first time when they perceive that they have been at risk [37]. Older individuals and heterosexuals may not feel at risk of HIV infection. Our finding that sub-Saharan African immigrants are at risk of presentation with advanced HIV disease corroborates previous reports that this group faces obstacles to HIV testing. A British study that investigated HIV testing practices among African immigrant communities found that although general HIV awareness was high, perception of individual risk was poor [38]. Furthermore, they found that cultural norms and stigma in immigrant communities often contributed to late presentation and remained a major barrier to HIV testing [11]. Immigrants usually present to care with immediate and specific needs, and the idea of getting tested for a disease before having symptoms, even when the risk of infection is high, is often rejected. Our finding that a large proportion of late HIV diagnoses were among non-immigrant men was also 
consistent with previous studies [2]. While women are systematically tested for HIV during pregnancy, men are not generally offered HIV tests on a routine basis.

Although several studies have investigated the factors associated with "late presentation" and "late testing," few studies have evaluated the characteristics of patients who get diagnosed with HIV early but delay presenting to care. We show that the risk factors for "delayed presentation to care" and "late testing" among patients who present with advanced HIV disease are different. First, we found that IDUs are more likely to test early and delay presenting to care. This result is consistent with previous studies [24] and demonstrates that IDU present with advanced HIV disease not because they are tested for HIV infrequently, but rather because they are not efficiently linked to care. In fact, IDU regularly receive HIV tests in specialized drug treatment centres. Moreover, because they are considered to be at high risk of HIV infection, physicians frequently offer them HIV tests during regular clinic visits. Despite their tendency to be diagnosed early, however, IDU are difficult to enroll and retain in care [21,25,39-43].

Second, although we found that rates of "late testing" increase with age, we did not find the same trend in the "delayed presentation to care" group. Patients aged 3049 years were at increased risk of "delayed presentation to care" and presentation to care with advanced HIV disease compared to patients aged $<30$ years, but patients aged $>50$ years were not. Unlike patients aged $>50$ years, those aged 30-49 years may seek an HIV test because of a perceived risk, but then delay presenting to care to avoid HIV-related stigma. The number of patients $>50$ years in our cohort was small, however, so any interpretation of this result should be made with caution. Finally, we found that patients who were followed in Brussels were twice more likely to be diagnosed early and delay presenting to care than patients who were followed in Northern France. Of note, as stated above, the proportion of patients diagnosed early with presentation to care at advanced HIV disease in Brussels was close to estimates in the Italian Cohort Naive Antiretrovirals [24]. This finding may be related to different testing and counselling services and/or linkage to care services in different countries. Girardi et al. for example have shown in their study that having no counselling at the time of first positive test were associated with a higher probability of delayed presentation to care[24], but unfortunately this information was not available in our datasets. Differences may be also explained by differences in patient characteristics. Our findings may be for example explained by the higher proportion of sub-Saharan African immigrants in Brussels when compared to Northern France. In multinomial logistic regression analysis, we adjusted our results for patient characteristics, including patient origin, but we may not have adjusted our results for all potential confounders. Differences between our study and the Italian study maybe also related to difference in the time period during which the analysis was conducted. As seen in previous studies, in our study rates of "late testing" and "delayed presentation to care" decreased overtime [24,33]. This trend is likely related to the increasing availability of more effective and less toxic cART regimens, as well as improvements in HIV care.

Our study has several limitations. First, our results cannot be generalized to locations outside of Northern France and Brussels, because the risk factors associated with "delayed presentation to care" and "late testing" may depend on population characteristics and local HIV screening practices. Although most of our results are consistent with previous studies, some risk factors for "delayed presentation to care" and "late testing" may depend on geography: patients in Brussels were more likely to be diagnosed early and delay presentation care compared to patients in Northern France. Second, although most data were collected prospectively, the study was designed after data collection had ended. We were therefore unable to assess the impact of variables such as incarceration, homelessness, illegal immigrant status, unemployment status, HIV testing history, psychological condition, counselling and community support on outcomes. These variables might influence rates of "delayed presentation to care" and "late testing." Third, the delay from initial HIV diagnosis to initial presentation to care, which was used to differentiate patients in the "late testing" and "delayed presentation to care" groups, was often self-reported and thus subject to recall bias. Finally, we may not have had enough statistical power to evaluate some of the risk factors associated with "delayed presentation to care", because the number of patients who were diagnosed early and delayed presentation to care was small.

\section{Conclusion}

Despite the wide availability of cART in Western Europe, access to care with advanced HIV disease remains common in France and Belgium, with almost one third of HIV-infected patients initiating care at CD4 counts $<200 / \mathrm{mm}^{3}$ and/or AIDS in recent years. This study shows that, although late HIV testing is the most frequent cause of delayed presentation to care, low rates of linkage to care also lead to late presentation. In our study, $17 \%$ of patients delayed initiating care after being diagnosed with HIV. Because the factors associated with "delayed presentation to care" differ from those associated with "late testing," different strategies should be developed to optimize early initiation of HIV care in each group. One method for increasing the proportion 
of patients who are diagnosed early is to broaden HIV screening practices. In France, the Haute Autorité de Santé $[44,45]$ recently recommended one-time universal, routine, voluntary HIV screening in the general population, and more frequent screening in higher-risk groups. General practitioners in particular should be encouraged to provide HIV tests on a routine basis, in order to improve access to care at the individual level and limit the spread of infection at the population level $[46,47]$. Interventions to improve linkage to care should be implemented alongside HIV screening strategies, particularly in marginalized groups such as IDU, who tend to be diagnosed early but to delay presentation to care.

\section{Abbreviations}

AIDS: Acquired immune deficiency syndrome; CART: combined antiretroviral therapy; Cl: confidence interval; HIV: human immunodeficiency virus; IDU: injection drogue use; IQR: interquartile range; MSM: men who have sex with men; OR: odds ratio.

\section{Acknowledgements}

We acknowledge the assistance of all the patients who participated in data collection in the five clinical centres in Northern France. We are indebted to Caroline Sloan for his valuable comments. We thank Stop-SIDA for their financial support.

\section{Author details}

${ }^{1}$ CIRE Nord, Lille, France. ${ }^{2}$ EA2694 Laboratoire de Biostatistique Faculté de Médecine de Lille, Lille, France. ${ }^{3}$ Service Universitaire des Maladies Infectieuse Saint-Luc, Bruxelles, Belgique. ${ }^{4} \mathrm{CH}$ Boulogne, Boulogne, France. ${ }^{5} \mathrm{CH}$ Dunkerque, Dunkerque, France. ${ }^{6}$ Service Universitaire des Maladies Infectieuses et du Voyageur, Tourcoing, France. ${ }^{7} \mathrm{CH}$ Lens, Lens, France. ${ }^{8} \mathrm{CH}$ Valenciennes, Valenciennes, France. ${ }^{9} \mathrm{COREVIH}$ Nord Pas-de-Calais, Tourcoing, France. ${ }^{10}$ ATIP Avenir INSERM U995, Lille, France.

\section{Authors' contributions}

$B N, J S, B V$ and $Y Y$ were involved in the overall study design and protocol development. BN, AV, PB, FB, PC, KC, CF, HM and HG collected the data and participated to their interpretation. BN and JS performed the statistical analysis. BN, HM, BV and YY participated in writing the manuscript, which all authors have reviewed and approved.

\section{Competing interests}

YY has received honoraria for presentation at workshops and consultancy honoraria from Bristol-Myers Squibb, Gilead, Glaxo-SmithKline, Merck, Pfizer, Roche and Tibotec. In Brussels, Tibotec has helped the implementation of the database. Other authors declare that they have no competing interests.

Received: 16 September 2010 Accepted: 12 January 2011

Published: 12 January 2011

\section{References}

1. Girardi $E$, Sabin CA, Monforte AD: Late diagnosis of HIV infection: epidemiological features, consequences and strategies to encourage earlier testing. J Acquir Immune Defic Syndr 2007, 46(Suppl 1):S3-S8.

2. Lanoy E, Mary-Krause M, Tattevin P, Perbost I, Poizot-Martin I, Dupont C, Costagliola D: Frequency, determinants and consequences of delayed access to care for HIV infection in France. Antivir Ther 2007, 12:89-96.

3. Wolbers M, Bucher HC, Furrer H, Rickenbach M, Cavassini M, Weber R, Schmid P, Bernasconi E, Hirschel B, Battegay M: Delayed diagnosis of HIV infection and late initiation of antiretroviral therapy in the Swiss HIV Cohort Study. HIV Med 2008, 9:397-405.

4. Borghi V, Girardi E, Bellelli S, Angeletti C, Mussini C, Porter K, Esposito R: Late presenters in an HIV surveillance system in Italy during the period 1992-2006. J Acquir Immune Defic Syndr 2008, 49:282-286.
5. Manavi K, McMillan A, Ogilvie M, Scott G: Heterosexual men and women with HIV test positive at a later stage of infection than homo- or bisexual men. Int J STD AIDS 2004, 15:811-814.

6. Sullivan AK, Curtis H, Sabin CA, Johnson MA: Newly diagnosed HIV infections: review in UK and Ireland. BMJ 2005, 330:1301-1302.

7. UK Collaborative HIV Cohort (UK CHIC) Steering Committee: Late diagnosis in the HAART era: proposed common definitions and associations with mortality. AIDS 2010, 24:723-727.

8. Chadborn TR, Baster K, Delpech VC, Sabin CA, Sinka K, Rice BD, Evans BG: No time to wait: how many HIV-infected homosexual men are diagnosed late and consequently die? (England and Wales, 1993-2002). AIDS 2005, 19:513-520.

9. Egger M, May M, Chene G, Phillips AN, Ledergerber B, Dabis F, Costagliola D, d'Arminio MA, de WF, Reiss P, Lundgren JD: Prognosis of HIV-1-infected patients starting highly active antiretroviral therapy: a collaborative analysis of prospective studies. Lancet 2002, 360:119-129.

10. Sterling TR, Chaisson RE, Moore RD: HIV-1 RNA, CD4 T-lymphocytes, and clinical response to highly active antiretroviral therapy. AIDS 2001, 15:2251-2257.

11. Castilla J, Sobrino P, De La FL, Noguer I, Guerra L, Parras F: Late diagnosis of HIV infection in the era of highly active antiretroviral therapy: consequences for AIDS incidence. AIDS 2002, 16:1945-1951.

12. Sterling TR, Chaisson RE, Keruly J, Moore RD: Improved outcomes with earlier initiation of highly active antiretroviral therapy among human immunodeficiency virus-infected patients who achieve durable virologic suppression: longer follow-up of an observational cohort study. J Infect Dis 2003, 188:1659-1665.

13. Mocroft A, Vella S, Benfield TL, Chiesi A, Miller V, Gargalianos $P$, d'Arminio MA, Yust I, Bruun JN, Phillips AN, Lundgren JD: Changing patterns of mortality across Europe in patients infected with HIV-1. EuroSIDA Study Group. Lancet 1998, 352:1725-1730.

14. Weinhardt LS, Carey MP, Johnson BT, Bickham NL: Effects of HIV counseling and testing on sexual risk behavior: a meta-analytic review of published research, 1985-1997. Am J Public Health 1999, 89:1397-1405.

15. Janssen RS, Holtgrave DR, Valdiserri RO, Shepherd M, Gayle HD, De Cock KM: The Serostatus Approach to Fighting the HIV Epidemic: prevention strategies for infected individuals. Am J Public Health 2001, 91:1019-1024.

16. Krentz HB, Auld MC, Gill MJ: The high cost of medical care for patients who present late (CD4 $<200$ cells/microL) with HIV infection. HIV Med 2004, 5:93-98.

17. Donnell D, Baeten JM, Kiarie J, Thomas KK, Stevens W, Cohen CR, Mclntyre J, Lingappa JR, Celum C: Heterosexual HIV-1 transmission after initiation of antiretroviral therapy: a prospective cohort analysis. Lancet 2010, 375:2092-2098.

18. Wood E, Kerr T, Marshall BD, Li K, Zhang R, Hogg RS, Harrigan PR, Montaner JS: Longitudinal community plasma HIV-1 RNA concentrations and incidence of HIV-1 among injecting drug users: prospective cohort study. BMJ 2009, 338:b1649.

19. InVS données au 30/06/2008. [http://www.invs.sante.fr/beh/2008/45_46/ beh_45_46_2008.pdf].

20. Sas A, Defraye A, Buziarsist J: Epidémiologie du SIDA et de l'infection à VIH en Belgique-Situation au 31 décembre 2007. Institut Scientifique de Santé Publique, Bruxelles; 2008, ISSN: D/2008/2505/54.

21. Yazdanpanah Y, Chene G, Losina E, Goldie SJ, Merchadou LD, Alfandari S, Seage GR III, Sullivan L, Marimoutou C, Paltiel AD, Salamon R: Incidence of primary opportunistic infections in two human immunodeficiency virusinfected French clinical cohorts. Int J Epidemiol 2001, 30:864-871.

22. Service des maladies infectieuses, Université catholique de Louvain. [http://www.saintluc.be/services/medicaux/vih/index.php].

23. Ancelle-Park R: Expanded European AIDS case definition. Lancet 1993, 341:441.

24. Girardi E, Aloisi MS, Arici C, Pezzotti P, Serraino D, Balzano R, Vigevani G, Alberici F, Ursitti M, D'Alessandro M, d'Arminio MA: Delayed presentation and late testing for HIV: demographic and behavioral risk factors in a multicenter study in Italy. J Acquir Immune Defic Syndr 2004, 36:951-959.

25. loannidis JP, Bassett R, Hughes MD, Volberding PA, Sacks HS, Lau J: Predictors and impact of patients lost to follow-up in a long-term randomized trial of immediate versus deferred antiretroviral treatment. $J$ Acquir Immune Defic Syndr Hum Retrovirol 1997, 16:22-30. 
26. Nacher M, El GM, Vaz T, Nasser V, Randrianjohany A, Alvarez F, Sobesky M, Magnien C, Couppie P: Risk factors for follow-up interruption of HIV patients in French Guiana. Am J Trop Med Hyg 2006, 74:915-917.

27. Lanoy E, Mary-Krause M, Tattevin P, Dray-Spira R, Duvivier C, Fischer $P$, Obadia Y, Lert F, Costagliola D: Predictors identified for losses to followup among HIV-seropositive patients. J Clin Epidemiol 2006, 59:829-835.

28. Lebouche B, Yazdanpanah Y, Gerard Y, Sissoko D, Ajana F, Alcaraz I, Boitte $P$, Cadore $B$, Mouton $Y$ : Incidence rate and risk factors for loss to follow-up in a French clinical cohort of HIV-infected patients from January 1985 to January 1998. HIV Med 2006, 7:140-145.

29. Couturier E, Schwoebel V, Michon C, Hubert JB, Delmas MC, Morlat P, Boue F, Simonpoli AM, Dabis F, Brunet JB: Determinants of delayed diagnosis of HIV infection in France, 1993-1995. AIDS 1998, 12:795-800.

30. Perez-Alvarez L, Villahermosa ML, Cuevas MT, Delgado E, Manjon N, Vazquez de PE, Medrano L, Contreras G, Thomson MM, Colomo C, Taboada JA: Single- and multidrug resistance mutations to reverse transcriptase and protease inhibitors: human immunodeficiency virus type 1-infected patients from two geographical areas in Spain. Spanish Groups for Antiretroviral Resistance Studies. J Hum Virol 2000, 3:150-156.

31. Wortley PM, Chu SY, Diaz T, Ward JW, Doyle B, Davidson AJ, Checko PJ, Herr M, Conti L, Fann SA: HIV testing patterns: where, why, and when were persons with AIDS tested for HIV? AIDS 1995, 9:487-492.

32. Poznansky MC, Coker R, Skinner C, Hill A, Bailey S, Whitaker L, Renton A, Weber J: HIV positive patients first presenting with an AIDS defining illness: characteristics and survival. BMJ 1995, 311:156-158

33. Girardi E, Sampaolesi A, Gentile M, Nurra G, Ippolito G: Increasing proportion of late diagnosis of HIV infection among patients with AIDS in Italy following introduction of combination antiretroviral therapy. $J$ Acquir Immune Defic Syndr 2000, 25:71-76.

34. McDonald AM, Li Y, Dore GJ, Ree H, Kaldor JM: Late HIV presentation among AIDS cases in Australia, 1992-2001. Aust N Z J Public Health 2003 27:608-613.

35. Klein D, Hurley LB, Merrill D, Quesenberry CP: Review of medical encounters in the 5 years before a diagnosis of HIV-1 infection: implications for early detection. J Acquir Immune Defic Syndr 2003, 32:143-152.

36. Samet JH, Freedberg KA, Savetsky JB, Sullivan LM, Stein MD: Understanding delay to medical care for HIV infection: the long-term non-presenter. AIDS 2001, 15:77-85.

37. Wasserfallen JB, Hyjazi A, Cavassini M: Comparison of HIV-infected patients' characteristics, healthcare resources use and cost between native and migrant patients. Int I Public Health 2009, 54:5-10.

38. Burns FM, Imrie JY, Nazroo J, Johnson AM, Fenton KA: Why the(y) wait? Key informant understandings of factors contributing to late presentation and poor utilization of HIV health and social care services by African migrants in Britain. AIDS Care 2007, 19:102-108.

39. Messiah A, Navaline $H$, vis-Vogel A, Tobin-Fiore D, Metzger D: Sociodemographic and behavioral characteristics associated with timeliness and retention in a 6-month follow-up study of high-risk injection drug users. Am J Epidemiol 2003, 157:930-939.

40. Chan AC, Palepu A, Guh DP, Sun H, Schechter MT, O'Shaughnessy MV, Anis AH: HIV-positive injection drug users who leave the hospital against medical advice: the mitigating role of methadone and social support. J Acquir Immune Defic Syndr 2004, 35:56-59.

41. Deyo RA, Inui TS: Dropouts and broken appointments. A literature review and agenda for future research. Med Care 1980, 18:1146-1157.

42. Ndiaye B, Ould-Kaci K, Salleron J, Bataille P, Bonnevie F, Choisy P, Cochonat K, Fontier C, Guerroumi H, Ajana F, Chaud P, Yazdanpanah Y: Incidence rate and risk factors for loss to follow-up in HIV-infected patients from five French clinical centres in Northern France - January 1997 to December 2006. Antivir Ther 2009, 14(4):567-75.

43. Friedland GH, Williams A: Attaining higher goals in HIV treatment: the central importance of adherence. AIDS 1999, 13(Suppl 1):S61-S72.

44. Dépistage de l'infection par le VIH. Nouvelles recommandations de la HAS. [http://www.has-sante.fr/portail/jcms/c_867079/depistage-delinfection-par-le-vih].

45. Yazdanpanah Y, Sloan CE, Charlois-Ou C, Le Vu S, Semaille C, Costagliola D, Pillonel J, Poullié Al, Scemama O, Deuffic-Burban S, Losina E, Walensky RP, Freedberg KA, Paltiel AD: Routine HIV screening in France: clinical impact and cost-effectiveness. PLoS One 2010, 5(10):e13132.
46. Delpierre C, Cuzin L, Lert F: Routine testing to reduce late HIV diagnosis in France. BMJ 2007, 334:1354-1356.

47. Delpierre C, Cuzin L, Lauwers-Cances V, Marchou B, Lang T: High-Risk groups for late diagnosis of HIV infection: a need for rethinking testing policy in the general population. AIDS Patient Care STDS 2006, 20:838-847.

\section{Pre-publication history}

The pre-publication history for this paper can be accessed here: http://www.biomedcentral.com/1471-2334/11/11/prepub

doi:10.1186/1471-2334-11-11

Cite this article as: Ndiaye et al:: Factors associated with presentation to care with advanced HIV disease in Brussels and Northern France: 19972007. BMC Infectious Diseases 2011 11:11.

\section{Submit your next manuscript to BioMed Central and take full advantage of:}

- Convenient online submission

- Thorough peer review

- No space constraints or color figure charges

- Immediate publication on acceptance

- Inclusion in PubMed, CAS, Scopus and Google Scholar

- Research which is freely available for redistribution

Submit your manuscript at www.biomedcentral.com/submit
C Biomed Central 